\author{
Al-wardah: Jurnal Kajian Perempuan, Gender dan Agama \\ Volume: 12 Nomor: 2 \\ ISSN: 1907-2740, E-ISSN: 2613-9367 \\ DOI: $\mathrm{xxx} \mathrm{xxxx} \mathrm{xxxx}$
}

\title{
PERENCANAAN DALAM PERKAWINAN DAN KELUARGA
}

\author{
Hamzah \\ IAIN Ternate, Indonesia \\ hamzahgiling@iain-ternate.ac.id
}

\begin{abstract}
Abstrak
Perkawinan dilakukan untuk mewujudkan kehidupan rumah tangga yang sakinah, mawaddah, dan rahmah. Namun tujuan ini tidak akan tercapai jika kedua pasangan tidak melaksanakan peran masing-masing, yaitu melaksanakan kewajiban dan menerima haknya. Untuk dapat melaksanakan peran masing-masing, maka perkaawinan perlu direncanakan sebelum melaksanakan pernikahan. Perencanaan pernikahan adalah untuk menyiapkan diri agar perjalanan pernikahan dapat berlangsung dengan baik, karena pernikahan tidak berjalan satu atau dua hari, tetapi sepanjang hidup dari kedua belah pihak. Fakta membuktikan banyak perkawinan hancur ditengah jalan, karena tidak memahami fungsi dan peran masing-masing. Oleh karena itu, perkawinan perlu direncanakan sebaik mungkin. Calon suami dan istri memiliki kesadaran (pengetahuan) dan kemampuan akan melaknanakan niat untuk melakukan pernikahan. Calon yang memiliki pengetahuan dan kemampuan serta atas kemauan yang kuat, itu tentunya dilakukan oleh orang yang dewasa dan berakal sehat dan memiliki status yang jelas, beragama Islam, dan memiliki restu dari kedua orangtua dari kedua belah pihak. Pengakuan dan restu dari orangtua adalah sebagai bentuk doa dan restu agar suatu perkawinan dapat berlangsung abadi, bahagia dan damai.
\end{abstract}

Kata Kunci: Perencanaan Perkawinan, Keluarga.

\begin{abstract}
Marriage is carried out to realize domestic life that is sakinah, mawaddah, and rahmah. But this goal will not be achieved if the two partners do not carry out their respective roles, namely carrying out obligations and accepting their rights. To be able to carry out their respective roles, the marriage needs to be planned before carrying out the marriage. Wedding planning is to prepare yourself so that the wedding trip can go well, because the wedding does not last a day or two, but throughout the life of both parties. Facts prove that many marriages break down in the middle of the road, because they do not understand their respective functions and roles. Therefore, marriage needs to be planned as well as possible. Prospective husband and wife have awareness (knowledge) and
\end{abstract}


ability to carry out the intention to carry out marriage. Candidates who have the knowledge and ability and with a strong will, it is certainly done by people who are mature and sensible and have a clear status, are Muslim, and have the blessing of both parents from both parties. Recognition and blessing from parents is as a form of prayer and blessing so that a marriage can last forever, happily and peacefully.

Keywords: Merriage planning, Family

\section{A. Pendahuluan}

Perkawinan atau pernikahan dalam literature fiqh berbahasa Arab disebut dengan dua kata, yaitu Nikah dan Zawaj. Kedua kata ini yang terpakai dalam kehidupan sehari-hari orang Arab dan banyka terdapat dalam Al-Qur'an dan hadis Nabi (Syarifuddin, 2006). Kata nakaha banyak ditemukan dalam al-Qur'an, seperti pada surah al-Baqarah ayat 230, an-Nisa' ayat 3 dan 22, dan kata zawaj terdapat pada surah al-Ahzab ayat 37.

Dari ayat-ayat di atas, Pernikahan pada kata nakaha ada dua pengertian, Pertama yaitu: kata nikah yang berarti "bergabung", "hubungan kelamin" dan juga "akad". Adanya dua kemungkinan arti ini karena kata nikah terdapat dalam al-Qur'an memang mengandung dua arti tersebut. Kedua Pernihakan mengandung arti hubungan kelamin dan bukan hanya sekedar akad nikah karena ada petunjuk dari hadis Nabi bahwa setelah akad nikah dengan laki-laki kedua perempuan itu belum boleh dinikai oleh mantan suaminya kecuali suami yang kedua telah merasakan nikmatnya hubungan kelamin dengan perempuan tersebut.

Ulasan di atas, memberikan kesimpulan hakikat perkawinan adalah akad yang membolehkan laki-laki dan perempuan melakukan sesuatu yang sebelumnya tidak dibolehkan. Pernikahan dilakukan untuk mengumpulkan dua jenis kelamin yang berbeda dalam ikatan sah bertujuan menghalalkan hubungan tersebut. Namun suatu perkawinan diperlukan suatu rencana yang baik dan matang agar tercapai tujuan dari pernikahan. Tulisan ini berupaya untuk menuangkan pemikiran-pemikiran tentang perencanaan pernikahan sebagai petunjuk apa yang harus dilakukan bagi calon mempelai sebelum masuk ke jenjang pernikahan.

\section{B. Pembahasan}

Perencanaan Perkawinan direncanakan sebaik mungkin agar perkawinan yang dilakukan untuk mengatur hubungan antara manusia dengan sesamanya yang menyangkut penyaluran kebutuhan biologis antarjenis, dan hak serta kewajiban yang berhubungan dengan akibat perkawinan tersebut dapat berjalan sesuai tujuan perkawinan. Rencana perkawinan dapat direncanakan sebagai berikut: 


\section{Memilih Calon Pasangan Yang Sehat Akalnya}

Memilih calon suami atau isteri yang sehat akalnya adalah merupakan persyaratan perkawinan. Persyaratan perkawinan adalah menentukan suatu perbuatan hukum, terutama yang menyangkut dengan sah atau tidaknya perbuatan tersebut dari segi hukum. Persyaratan mengandung arti sesuatu yang harus ada. Oleh karena itu, jika ingin melakukan perkawinan harus mengetahui benar kondisi calon, baik laki-laki atau perempuan, apakah sehat akalnya atau tidak. Sehat akalnya akan mempengaruhi cara berpikir dan bertindak karena suatu perkawinan akan sah hanya bila dilakukan oleh orang-orang yang sehat akalnya.

Untuk melakukan kewajiban-kewajiban dan hak dalam perkawinan tentunya harus dilakukan oleh orang yang sehat akalnya, karena ketentuan-ketentuan tersebut merupakan ajaran agama. Dalam suatu hadis dinyatakan sebagaimana artinya "Tidak beragama bagi orang yang tidak berakal".

\section{Memilih Calon Pasangan yang baligh (Dewasa)}

Memilih calon pasangan yang baligh (dewasa) adalah merupakan persyaratan perkawinan, di mana disyaratkan bagi calon mempelai laki-laki dan perempuan orang sudah dewasa. Dewasa menjadi persyaratan bagi calon mempelai laki-laki dan perempuan, karena orang dewasa dan sehat akalnya dianggap mampu menyelesaikan dan melaksanakan kewajiban-kewajiban dan hak-hak yang harus dipenuhinya.

\section{Memiliki Identitas yang jelas}

Memiliki identitas yang jelas bagi calon suami dan istri adalah persyaratan yang mutlak, karena dengan mengetahui identitas yang jelas akan mengurangi resiko yang tidak baik, seperti apakah calon pasangan tersebut benar-benar belum menikah, dan mengetahui secara jelas dari keluarga yang baik atau tidak. Persyaratan ini jangan diabaikan,karena banyak pengalaman dan cerita yang melakukan perkwinan tanpa mengetahui identitas yang jelas akan merugikan masing-masing calon. Identitas yang jelas dapat dilihat dari kartu tanda Penduduk (KTP), atau menyuruh orang lain untuk mengetahui keberadaannya, baik tempat tinggal, pekerjaan dan keturunan dari keluarga siapa.

Keduanya jelas identitasnya dan dapat dibedakan dengan lainnya, baik yang menyangkut nama, jenis kelamin, keberadaan, dan hal lain yang berkenaan dengan dirinya. Adanya syariat peminangan yang terdapat dalam al-Qur'an dan hadis Nabi kiranya merupakan suatu syarat supaya kedua calon pengantin telah sama-sama tahu mengenai pihak lain, secara baik dan terbuka. Keduanya sama-sama beragama Islam dan antara keduanya tidak terlarang melangsungkan perkawinan. 


\section{Memiliki Agama Yang Jelas (Islam)}

Memiliki agama yang jelas (Islam) adalah persyaratan utama, karena dalam alQur'an surah al-Baqarah ayat 221 dilarang menikahi wanita dan laki-laki musyrik. Terjemahannya:

dan janganlah kamu menikahi wanita-wanita musyrik, sebelum mereka beriman. Sesungguhnya wanita budak yang mukmin lebih baik dari wanita musyrik, walaupun Dia menarik hatimu. dan janganlah kamu menikahkan orang-orang musyrik (dengan wanita-wanita mukmin) sebelum mereka beriman. Sesungguhnya budak yang mukmin lebih baik dari orang musyrik, walaupun Dia menarik hatimu. mereka mengajak ke neraka, sedang Allah mengajak ke surga dan ampunan dengan izin-Nya. dan Allah menerangkan ayat-ayat-Nya (perintah-perintah-Nya) kepada manusia supaya mereka mengambil pelajaran.

Ayat ini menjelaskan bahwa suatu pernikahan hanya boleh dilakukan jika kedua calon pasangan beragama Islam. Dengan iman, seorang laki-laki dan wanita akan mencapai kesempurnaan agamanya, memelihara keluarga dan mendidik anak-anaknya dengan apendidikan yang baik dan menghiasi anaknya dengan akhlak yang mulia. Dalam suatu hadis dari Ibnu Umar yang diriwayatkan Ibnu Majah, yang artinya "Janganlah kalian menikahi wanita karena kecantikannya, bisa jadi kecantikannya akan mengundang malapetaka, dan janganlah kalian menikahi wanita karena harta bendanya, bisa jadi harta bendanya akan membuatnya berlaku semena-mena. Dan nikahilah wanita karena agamanya, sungguh budak wanita hitam dan beragama itu lebih baik.

\section{Memiliki Status Yang Jelas}

Yang dimaksud memiliki status yang jelas, adalah bahwa calon pasangan baik pasangan laki-laki atau perempuan, keduanya tidak terlarang melangsungkan perkawinan. Yang dimaksud dengan larangan perkawinan adalah orang-orang yang tidak boleh melakukan perkawinan, yaitu perempuan-perempuan mana saja yang tidak boleh dikawini oleh seorang laki-laki, atau sebaliknya laki-laki mana saja yang tidak boleh mengawini seorang perempuan. Larangan perkawinan itu adalah larangan yang selamanya dan larangan disebabkan karena adanya hubungan perkawinan. Lihat pada surah an-Nisa' ayat 22 dan 23.

\section{Memiliki Kemauan yang Kuat Atas Pernikahan}

Yang dimaksud memilki kemauan yang kuat atas pernikahan, bahwa perkawinan yang dilakukan adalah atas dasar keinginan dan kesadaran dari kedua pasangan tanpa ada paksaan. Oleh karena itu, perkawinan harus disetujui oleh kedua bela pihak. 
Karena salah satu rukun nikah adalah adanya akad (perjanjian) yang disetujui. Perilaku yang didasarkan oleh keinginan yang kuat atas kesadaran dan keinginan sendiri memiliki implikasi yang positif. Hubungan yang diawali oleh keinginan dan kemauan yang kuat menjadi motivasi dan dorongan dalam melaksanakan kewajiban-kewajiban dan hak-hak yang dalam pernikahan dan keluarga untuk selanjutnya. Motivasinya akan hidup dan memiliki tanggung-jawab. Banyak perkawinan yang hancur karena di mulai dengan paksaan dan tidak memiliki tanggung-jawab.

Dalam Undang-undang Perkawinan No 1 Tahun 1974, terdapat beberapa prinsip demi menjamin cita-cita luhur perkawinan. Dari undang-undang ini diharapkan agar supaya pelaksanaan perkawinan dapat lebih sempurna dari masa yang sudah-sudah. Oleh karena itu bukannya tidak mungkin adanya pembaharuan atau perubahan dalam pelaksanaan hukum. Menurut Sosroatmodjo (1987), adapun prinsip-prinsip tersebut ialah antara lain: azas sukarela, partisipasi keluarga, perceraian dipersulit, poliygami dibatasi secara ketat, kematangan calon mempelai dan memperbaiki derajat kaum wanita.

Undang-undang menentukan bahwa perkawinan harus didasarkan atas persetujuan kedua calon mempelai (Pasal 6 ayat (1). Oleh karena perkawinan mempunyai maksud agar supaya suami istri dapat membentuk keluarga yang kekal dan bahagia, dan sesuai pula hak asasi manusia, maka suatu perkawinan harus mendapat persetujuan kedua calon suami istri, tanpa ada paksaan dari pihak manapun.

\section{Memilki persetujuan dari Wali (orangtua)}

Yang dimaksud memiliki persetujuan dari Walim (orangtua) adalah bahwa perkawinan itu direstui oleh kedua orangtua, baik orangtua dari calon laki-laki ataupun sebaliknya, yaitu orangtua dari calon perempuan. Persetujuan mutlak dari orangtua adalah sebagai pengalihan tanggugjawab orangtua kepada calon mempelai. Karena selama ini orangtua sebagai sandarac utama, maka setelah menikah akan bertukar posisi. Persetujuan orangtua juga untuk mendapat restu dan keridhaan orangtua agar kehidupan berumah-tangga dalam keluarga dapat berjalan dengan baik. Dalam bebarapa ayat al-Qur' an dijelaskan secara nyata, setelah kepatuhan kepada Allah, maka harus patuh dan berbuat baik kepada orangtua.

Dari uraian di atas, pernikahan harus direncanakan secara baik, tidak hanya materi tetapi juga persiapan individu itu sendiri jauh lebih penting diutamakan, misalnya calon suami dan istri adalah orang yang berakal dan dewasa. Dalam istilah Hukum Islam, orang yang dewasa dan berakal disebut mukallaf, yang dibebani hukum, dalam usul fikih, mukallaf disebut juga al-M ahkum 'alaih (subjek hukum). Orang mukallaf adalah orang yang telah dianggap mampu bertindak hukum, baik yang berhubungan 
perintah Allah SWT maupun dengan larangan-Nya (Aziz, 1997). Oleh karena itu, orang-orang yang sudah dewasa dan berakallah yang boleh melakukan pernikahan.

Menurut Fatchurrahman (1986), seseorang yang sudah dibebani hukum (mahkum 'alaih) memiliki persyaratan, yaitu: (1) sanggup memahami perintah-perintah yang dibebankan kepada dirinya; (2) mempunyai kemampuan menerima beban. Dua hal di atas, sangat perlu diperhatikan, yaitu seseorang yang akan menikah harus memiliki kesadaran (pengetahuan) dan kemampuan kewajiban-kewajiban dan hak-hak yang harus dilaksanakan dalam Pernikahan. Fakta membuktikan banyaknya pernikahan hancur ditengah jalan, karena tidak memiliki pengetahuan dan kemampuan dalam melaksanakan kewajiban-kewajiban dan memberikan hak kepada pasangan. Pada prinsipnya kemampuan berbuat seseorang diukur dengan kesempurnaan akal dan kesempurnaan akal seseorang dapat diukur dengan kedewasaannya. Sebab kedewasaannya itu menunjukkan bahwa akalnya telah sempurna.

\section{Simpulan}

Dari pembahasan di atas, dapat disimpulkan perencanaan perkawinan dalam pernikahan harus memperhatikan 7 unsur, yaitu memilih calon pasangan yang sehat akalnya, memilih calon pasangan yang baligh (dewasa), memiliki identitas yang jelas, memiliki agama yang jelas (Islam), memiliki status yang jelas, memiliki kemauan yang kuat atas pernikahan bukan karena paksaan dan memilki persetujuan dari wali (orangtua).

\section{Daftar Pustaka}

Syarifuddin, A. (2006). Hukum Perkawinan Islam Indonesia. Jakarta: Kencana.

Sosroatmodjo, A. (1987). Hukum Perkawinan di Indonesia. Jakarta: Bulan Bintang.

Aziz, D.A. (1997). Ensiklopedi Hukum Islam. Jakarta: PT. Ichtiar Baru van Hoeve.

Fatchturrahman, M.Y. (1986). Dasar-dasar Pembinaan Hukum Islam. Bandung: PT. Al-Ma'arif. 